\title{
Retrospective Evaluation of Adrenal Incidentaloma Patients Admitted to Endocrinology Outpatient Clinic
}

\section{Endokrinoloji Polikliniğine Başvuran Adrenal Insidentaloma Olgularimizin Retrospektif Değerlendirilmesi}

İlker Cordan ${ }^{1}$,

Mustafa Can ${ }^{1}$,

Muhammet Kocabas ${ }^{1}$,

Melia Karakose ${ }^{1}$,

Mustafa Kulaksizoglu ${ }^{1}$,

Feridun Karakurt ${ }^{1}$ Faculty of Medicine, Department of Internal Medicine, Konya, Turkey

Geliş Tarihi/Received: 12 July 2019

Kabul Tarihi/Accepted: 3 January 2020

Address correspondence to: llker Cordan, Necmettin Erbakan University Meram Faculty of Medicine, Department of Internal Medicine, Konya, Turkey

e-mail: dr.ilkercordan@windowslive.com

\section{ORCID}

Ilker Cordan

https://orcid.org/0000-0002-5225-4905

Mustafa Can

https://orcid.org/0000-0003-3241-4104

Muhammet Kocabas

Melia Karakose

https://orcid.org/0000-0001-7990-8350

Mustafa Kulaksizoglu

https://orcid.org/0000-0001-9908-7449

Feridun Karakurt

https://orcid.org/0000-0001-7629-9625
${ }^{1}$ Necmettin Erbakan University, Meram

https://orcid.org/0000-0002-6473-4164

\begin{abstract}
Öz
Amaç: Bu çalışmada, farklı şikayetler nedeniyle yapılan görüntülemelerde adrenal insidentaloma saptanan ve endokrinoloji polikliniğimize yönlendirilen hastaların hormonal durumlarını, tedavilerini ve histopatolojik tanılarını gözden geçirmeyi amaçladık.

Hastalar ve Yöntem: Çalışmaya 2015-2018 yılları arasında farklı şikayetler nedeniyle yapılan görüntülemelerde adrenal insidentaloma saptanan ve endokrinoloji polikliniğine yönlendirilen 217 hasta alındı. Biyokimyasal olarak $1 \mathrm{mg}$ deksametazon supresyon testi ve 24 saatlik idrar serbest kortizolü, 24 saatlik idrarda metanefrin ve normetanefrin düzeyleri tüm hastalarda değerlendirildi. Hipertansiyonu olan hastalara aldesteron/renin aktivitesi açısından tarama yapıldı. Adrenal insidentalomaların BT veya MRG ile değerlendirilen görüntüleme özellikleri tarandı.

Bulgular: Olguların değerlendirmesinde; 180'i (\%83) nonfonksiyonel, 37'si (\%17) fonksiyonel olarak değerlendirildi. Fonksiyonel olarak değerlendirilen 37 hastanın; 10'unda (\%4.6) feokromasitoma, 5 'inde (\%2.3), Cushing sendromu, 9'unda (\%4.1), subklinik Cushing sendromu, 13 'ünde(\%6) primer hiperaldesteronizm saptandı. Nonfonksiyonel olarak değerlendirilen 180 hastanın; 7'sinde metastatik hastalık (3'ü küçük hücre dışı akciğer karsinomu, 1'i meme kanseri, 1'i prostat karsinomu ve 2'si primeri bilinmeyen kanser), 4'ü myelolipom, 1'i ganglionörom, 1'i kisthidatik, 2'sinde adrenokortikal karsinom saptandı.

Sonuç: Bu çalışmanın sonucuna göre adrenal insidentalomalı hastalarda hormonal olarak aktif olma durumu nadir değildir. Bazı adrenal kitleler malign özellik taşıyabilmektedir. Bu nedenle adrenal insidentaloma hem fonksiyonel olup olmadığı hem de malign-benign lezyon ayırımı acısından tetkik edilmesi gereken bir durumdur.
\end{abstract}

Anahtar Kelimeler: Adrenal insidentaloma, feokromositoma, Cushing sendromu, hiperaldesteronizm Abstract

Aim: The aim was to review the hormonal status, treatment and histopathological diagnosis of patients admitted to our endocrinology outpatient clinic with the diagnosis of adrenal incidentaloma.

Patients and Methods: Between 2015-2018, 217 patients with adrenal incidentaloma who were admitted to the endocrinology outpatient clinic were included in the study. $1 \mathrm{mg}$ overnight dexamethasone suppression test (DST), 24 hour urine free cortisol, 24-hour urine methanephrine and normetanephrine levels were evaluated in all patients.Patients who also have hypertension or hypokalemiawere screened for the plasma aldosterone/renin activity ratio. CT or MRI imaging properties of adrenal incidentalomas were screened.

Results: In the evaluation of cases; $180(83 \%)$ of the masses were evaluated as non-functional and $37(17 \%)$ as functional. Of the 37 patients evaluated as having functional adrenal mass; $10(4.6 \%)$ pheochromocytoma, $5(2.3 \%)$ Cushing's syndrome, 9 (4.1\%) subclinical Cushing's syndrome and $13(6 \%)$ primary hyperaldesteronism were detected. In 180 patients who were evaluated as having non-functional adrenal mass; metastatic disease in 7 ( 3 non-small cell lung cancer, 1 breast cancer, 1 prostate carcinoma and 2 unknown primary cancer), myelolipoma in 4, ganglioneuroma in 1, hydatid cyst in 1, adrenocortical carcinoma in 2 patients were detected.

Conclusion: According to the results of this current study, it is not uncommon for adrenal incidentalomas to be functional. Some adrenal masses may have malignant features. For this reason, adrenal incidentaloma is a condition that should be examined both in terms of functionality and malignancy potential.

Key words: Adrenal incidentaloma, pheochromocytoma, Cushing's syndrome, hyperaldesteronism

Cite this article as: Cordan I, Can M, Kocabas M, Karakose M, Kulaksizoglu M, Karakurt F. Retrospective Evaluation of Adrenal Incidentaloma Patients Admitted to Endocrinology Outpatient Clinic. Selcuk Med J 2021;37(1): 52-56
Disclosure: None of the authors has a financial interest in any of the products, devices, or drugs mentioned in this article. The research was not sponsored by an outside organization. All authors have agreed to allow full access to the primary data and to allow the journal to review the data if requested. 


\section{INTRODUCTION}

An adrenal incidentaloma is an adrenal mass that is found in an imaging examination performed for other reasons, typically without the suspicion of any adrenal disease. Radiological studies report that the incidence is $3 \%$ in the 5 th decade and increases up to $10 \%$ with age (1-2). Approximately $80 \%$ of adrenal incidentalomas are non-functional adrenal adenomas. Studies reported the prevalence of subclinical Cushing's syndrome to be $5 \%$, pheochromocytoma as $5 \%$, adrenocortical carcinoma as $5 \%$, adrenal metastases as $2,5 \%$, and primary hyperaldosteronism as $1 \%$ in patients with adrenal incidentaloma. Other causes are benign cysts, ganglioneuroma, myelolipoma, etc (3-4). Computed tomography (CT) and Magnetic Resonance Imaging (MRI) are the main imaging modalities for adrenal incidentalomas. An attenuation coefficient of $10 \mathrm{HU}$ or less in a noncontrast CT and rapid washout of the contrast agent after 10 or 15 minutes are important indicators for the detection of benign lesions (5). In MRI, adenomas are seen as hypo or isointense in T1-weighted images and hyper or isointense in T2-weighted images (6-7).

It is recommended that all adrenal incidentaloma patients should be evaluated for Cushing's syndrome and pheochromocytoma to determine whether they are functional in terms of hormone secretion, and patients who also have hypertension or hypokalemiashould be evaluated for primary hyperaldosteronism. In patients with adrenal incidentaloma, 24-hour urine fractionated metanephrines are used as a screening test for pheochromocytoma. $1 \mathrm{mg}$ overnight dexamethasone suppression test (DST), 24-hour urine free cortisol, midnight serum cortisol and midnight salivary cortisol are used as screening test for Cushing syndrome. Determination of the plasma aldosterone $(\mathrm{ng} / \mathrm{dL}) /$ plasma renin activity $(\mathrm{ng} / \mathrm{mL} / \mathrm{h})$ ratio is used to exclude primary aldosteronism. Surgical treatment in patients withadrenal incidentalomais recommended for patients with suspicious or malignant radiological appearance, overt hormone hypersecretion syndromes, increase in mass size by $10 \mathrm{~mm}$ or more during follow-up, and subclinical Cushing's syndrome where comorbidities associated with excess glucocorticoid did not improve with medical treatment. It is advocated that surgery should be prioritized for lesions over $60 \mathrm{~mm}$ in size (8-9).

In this study, we aimed to review the age, sex, clinical and laboratory characteristics of patients with adrenal incidentaloma who were referred to our endocrinology outpatient clinic, whether the adrenal masses are functional in terms of hormone secretion, radiological imaging characteristics, treatment modalities and histopathological diagnoses of patients who undervent surgical treatment.

\section{PATIENTS AND METHODS}

The study included 217 patients over 18 years of age who were followed-up with the diagnosis of adrenal incidentaloma between January 2015 and September 2018 in Necmettin Erbakan University Meram Medical Faculty Endocrinology Outpatient Clinic. Ethics committee approval was obtained from Necmettin Erbakan University Meram Medical Faculty Non-Invasive Clinical Research Ethics Committee with the decision numbered 2019/1648. Demographic, clinical and laboratory data of patients were recorded from the patient files. To determine whether the adrenal masses were functionally active, the results of $1 \mathrm{mg}$ overnightDST, free cortisol levels in 24-hour urine, metanephrine-normetanephrine levels in 24-hour urine, and plasma aldosterone and plasma renin activity levels in patients with hypertension were recorded for all patients from files. Imaging characteristics of the patients evaluated by CT or MRI were recorded from the files. The treatments and the histopathological diagnoses of adrenal incidentaloma in patients subjected to adrenalectomy were recorded from the files.

\section{Statistical analysis}

Statistical analyzes were performed using SPSS 22.0 (Statistical Package for Social Sciences). Continuous variables were given as mean \pm standard deviation if the distribution was normal, and median (minimum-maximum) if the distribution was not normal. When parametric test assumptions were met, independent samples $t$ test was used to compare the differences between the two groups. When parametric test assumptions were not provided, Mann-Whitney $U$ test was used to compare independent group differences. In addition, Pearson and Spearman correlation analyzes were used to examine the relationship between variables. For differences, $p$ $<0.05$ was considered statistically significant.

\section{RESULTS}

Of the 217 patients included in the study, 143 $(65.9 \%)$ were female and $74(34.1 \%)$ were male. The mean age was $54.8 \pm 12.6$ years. The mean mass size was $26.8 \pm 14.8 \mathrm{~mm}$. Of the 217 cases, $105(48.4 \%)$ had a mass on the left, $85(39.2 \%)$ on the right, and the masses of $27(12.4 \%)$ patients were bilateral. 
Of 217 patients, 52 (24\%) had hypertension (Table 1). In functional evaluation of 217 patients; adrenal incidentalomas were non-functional in 180 (83\%) patients and functional in $37(17 \%)$ patients. Of the 37 patients who were evaluated as having functional adrenal mass, 10(4.6\%) had pheochromocytoma, $5(2.3 \%)$ had Cushing's syndrome, $9(4.1 \%)$ had subclinical Cushing's syndrome, and 13(6\%) had primary hyperaldesteronism (Table 1).

Of the 180 patients evaluated as having nonfunctional adrenal incidentaloma; $7(3,2 \%)$ had metastatic disease ( 3 non-small cell lung carcinoma, 1 breast cancer, 1 prostate carcinoma and 2 cancer of unknown origin), 4(1,8\%) had myelolipoma, $1(0,4 \%)$ had ganglioneuroma, $1(0,4 \%)$ had cyst hydatid, $2(0,9 \%)$ had adrenocortical carcinoma (Table 1$)$.

\section{DISCUSSION}

Adrenal incidentaloma is the general name of lesions detected during imaging studies performed for other reasons to people who do not have any adrenal gland related complaints or physical examination findings. Generally, lesions with a diameter of $10 \mathrm{~mm}$ or greater are considered adrenal incidentaloma.
Development of imaging techniques, aging, presence of metabolic syndrome, white race origin, frequency of hospital admission and female gender are seen as major factors increasing the incidence of adrenal incidentaloma. In a study conducted by Çömlekci et al., with 376 adrenal incidentaloma patients, it was found that the mean age was $54.7 \pm 13.1$ and it was seen more frequently in women (70\%) (10). In our study, the mean age was $54.8 \pm 12.6$ years in accordance with the literature. Likewise, it was found to be more frequent in women (65.9\%). Approximately $50-60 \%$ of adrenal masses are located in the right adrenal gland, $30-40 \%$ in the left adrenal gland, and $10-15 \%$ in both adrenal glands. However, when ultrasonography is used as an imaging modality, adrenal masses are observed more frequently in the right adrenal gland due to insufficient imaging of the left adrenal gland compared to CT (11-13). In a study conducted by Kutbay et al.(14), it was found that $51.3 \%$ of adrenal masses were on the left, $38.5 \%$ were on the right and $10.2 \%$ were bilateral. In our study, the localization of the adrenal incidentalomas was made by CT and MRI and $48.4 \%$ of the masses were on the left, $39.2 \%$ on the right and $12.4 \%$ were bilateral.

Table 1. Demografic, hormonal and histopathological characteristics of adrenal incidentaloma patients

\begin{tabular}{|c|c|}
\hline & All Population $n=217(\%)$ \\
\hline \multicolumn{2}{|l|}{ Gender } \\
\hline Female & $143(65,9)$ \\
\hline Male & $74(34,1)$ \\
\hline Age (year) & $54.8 \pm 12.6$ \\
\hline \multicolumn{2}{|l|}{ Hypertension } \\
\hline Yes & $52(24)$ \\
\hline No & $165(76)$ \\
\hline Tumor size (mm) & $26.8 \pm 14.8$ \\
\hline \multicolumn{2}{|l|}{ Tumor localization } \\
\hline Left & $105(48.4)$ \\
\hline Right & $85(39.2)$ \\
\hline Bilateral & $27(12.4)$ \\
\hline \multicolumn{2}{|l|}{ Functional evaluation } \\
\hline Non-functional & $180(83)$ \\
\hline Functional & $37(17)$ \\
\hline Non-functional adrenal mass evaluation & $180(83)$ \\
\hline Non-Functional adrenal adenom & $165(76)^{\prime}$ \\
\hline Metastatic disease & $7(3,2)$ \\
\hline Myelolipoma & $4(1,8)$ \\
\hline Ganglioneuroma & $1(0,4)$ \\
\hline Cyst hydatid & $1(0,4)$ \\
\hline Adrenocortical carcinoma & $2(0,9)$ \\
\hline Functional adrenal mass evaluation & $37(17)$ \\
\hline Pheochromocytoma & $10(4.6)$ \\
\hline Cushing's syndrome & $5(2.3)$ \\
\hline Subclinical Cushing's syndrome & $9(4.1)$ \\
\hline Primary hyperaldesteronism & $13(6)$ \\
\hline
\end{tabular}


If Cushing's syndrome is left untreated, $50 \%$ of patients will die within five years, especially for vascular reasons. In cases with Cushing's syndrome, infections and thromboembolic events are more common than in the normal population. Despite treatment, cardiovascular risk may persist. In patients with persistent moderate hypercortisolemia, mortality rate increases by $3.8-5$ times compared to normal population (15). Pheochromocytoma is a potentially curable cause of hypertension and, if not detected, poses a high risk of morbidity and mortality, particularly during surgical procedures and pregnancy. Pheochromocytoma is seen in 0.2$0.6 \%$ of the hypertensive population (16-17). It is seen in $2-4 \%$ of young hypertensive population (18). Malignant pheochromocytomas constitute $8-12 \%$ of pheochromocytomas. 5-year survival in malignant pheochromocytoma is $30-60 \%$ (19-21).

Primary hyperaldosteronism is seen in 1.3$10 \%$ of hypertension patients and is a potentially curable cause of secondary hypertension. Primary hyperaldosteronism patients have higher cardiovascular morbidity and mortality than essential hypertension patients with the same age, sex and blood pressure values(22-23). Adrenocortical carcinoma is a rare and highly malignant tumor with a poor prognosis. $20-30 \%$ of adrenocortical carcinomas are detected as an incidental adrenal mass. While the 40 -month survival rate is $50 \%$ in patients without metastasis, this rate is $10 \%$ in metastatic patients (24). Adrenal gland is one of the most common metastatic sites of malignant tumors. Adrenal metastasis was detected in $13-17 \%$ of autopsy series of metastatic tumors. Adrenal metastasis is most commonly seen in lung and kidney tumors (25-27).

In the management of patients with adrenal incidentaloma, the differential diagnosis of malignant, metastatic and hormone-releasing functional masses from benign and non-functional masses should be made because of their serious effects on morbidity and mortality. In a study conducted by Mantero et al. with 1004 adrenal incidentaloma cases, 83\% of the adrenal incidentalomas were evaluated as non-functional, $17 \%$ as functional $(5.28 \%$ pheochromocytoma, $9.96 \%$ hypercortisolemia, and $1.75 \%$ primary hyperaldesteronism) (11). In our study, functional evaluation of 217 patients; 180 (83\%) were non-functional and $37(17 \%)$ were functional. Of the 37 patients who were evaluated as having functional adrenal lesion, 10(4.6\%) had pheochromocytoma, $5(2.3 \%)$ had Cushing's syndrome, $9(4.1 \%)$ had subclinical Cushing's syndrome, and $13(6 \%)$ had primary hyperaldesteronism. Of the 180 patients evaluated as having non-functional adrenal incidentaloma; $7(3,8 \%)$ had metastatic disease (3 non-small cell lung carcinoma, 1 breast cancer, 1 prostate carcinoma and 2 cancer of unknown origin), 4 $(2,2 \%)$ had myelolipoma, $2(1,1 \%)$ had adrenocortical carcinoma, 1 had ganglioneuroma and 1 had cyst hydatid. The data we obtained as a result of our study were found to be compatible with previous studies on this subject.

Our study has some limitations. This is a singlecenter study and the sample size is relatively small. The results of our study were consistent with previous studies in the literature, but primary hyperaldosteronism was detected at a higher rate. According to the results of this study, it is not uncommon for adrenal incidentalomas to be functional. In addition, some adrenal masses may be malignant. Therefore, adrenal incidentaloma is a condition that should be examined in terms of both functionality and malignant-benign lesion distinction.

Conflict of interest: Authors declare that there is no conflict of interest between the authors of the article.

Financial conflict of interest: Authors declare that they did not receive any financial support in this study.

Address correspondence to: Ilker Cordan, Necmettin Erbakan University, Meram Faculty of Medicine, Department of Internal Medicine, Konya, Turkey e-mail: dr.ilkercordan@windowslive.com

\section{REFERENCES}

1. Osella G, Terzolo M, Borretta G, et al. Endocrine evaluation of incidentally discovered adrenal masses (incidentalomas), J ClinEndocrinol Metab 1994;79(6):1532-9.

2. Barzon L, Sonino N, Fallo F, et al. Prevalence and natural history of adrenal incidentalomas. Eur $\mathrm{J}$ Endocrinol 2003;149(4):273-85.

3. Young WF Jr. Management approaches to adrenal incidentalomas: A view from Rochester, Minnesota. Endocrinol Metab Clin North Am 2000;29:159-85.

4. Grumbach MM, Biller BM, Braunstein GD, et al. Management of the clinically inapparent adrenal mass (incidentalomall). Ann Intern Med 2003;138:424-9.

5. Gupta P, Bhalla A, Sharma R. Bilateral adrenal lesions. J Med Imaging Radiat Oncol 2012;56(6):636-45.

6. Terzolo M, Stigliano A, Chiodini I, et al. AME position statement on adrenal incidentaloma. Eur $\mathrm{J}$ Endocrinol 2011;164:851-70.

7. Kanagarajah $\mathrm{P}$, Ayyathurai R, Manoharan M, et al. Current concepts in the management of adrenal incidentalomas. Urol Ann 2012;4:137-44.

8. Aron D, Terzolo M, Cawood TJ. Adrenal incidentalomas. Best 
Pract Res Clin Endocrinol Metab 2012;26:69-82.

9. Ilias I, Sahdev A, Reznek RH, et al. The optimal imaging of adrenal tumours: A comparison of different methods. Endocr Relat Cancer 2007;14:587-99.

10. Comlekci A, Yener S, Ertilav S, et al. Adrenalin cidentaloma, clinical, metabolic, follow up aspects: Single centre experience. Endocrine 2010;37(1):40-6.

11. Mantero F, Terzolo M, Arnaldi G, et al. A survey on adrenal incidentaloma in Italy. Study Group on Adrenal Tumors of the Italian Society of Endocrinology. J Clin Endocrinol Metab 2000;85(2):637-44.

12. Barzon L, Scaroni C, Sonino N, et al. Incidentally discovered adrenal tumours: Endocrine and scintigraphic correlates. J Clin Endocrinol Metab 1998;83: 55-62.

13. Flecchia D, Mazza E, Carlini M, et al. Reduced serum levels of dehydroepiandrosteronesulphate in adrenal incidentalomas: A marker of adrenocortical tumor. Clin Endocrinol 1995;42: 129-34.

14. Kutbay NO, Yürekli BS, Pehlivan E, et al. Clinical features of 80 cases with adrenal incidentaloma. Ege $\mathrm{J}$ Med 2015;54(3):120-3.

15. Nieman LK, Biller BM, Findling JW, et al. The diagnosis of Cushing's syndrome: An Endocrine Society Clinical Practice Guideline. J Clin Endocrinol Metab 2008;93:1526-40

16. Ariton M, Juan CS, Av Ruskin TW. Phaeochromocytoma: Clinical observations from a Brooklyn tertiary hospital. Endocr Pract 2000;6:249-52.

17. Omura M, Saito J, Yamaguchi K. Prospective study on the prevalence of secondary hypertension among hypertensive patients visiting a general outpatient clinic in Japan. Hypertens Res 2004;27:193-202.

18. Noilhan C, Barigou M, Bieler L. Causes of secondary hypertension in the young population: A monocentric study. Ann Cardiol Angeiol (Paris) 2016;65:159-64.
19. Melicow MM. One hundred cases of pheochromocytoma (107 tumors) at the Columbia-Presbyterian Medical Center, 19261976: A clinicopathological analysis. Cancer 1977;40:19872004.

20. Scott HW, Jr Reynolds V, Green N, et al. Clinical experience with malignant pheochromocytomas. Surg Gynecol Obstet 1982;154:801-18.

21. John H, Ziegler WH, Hauri D, et al. Pheochromocytomas: Can malignant potential be predicted? Urology 1999;53:67983.

22. Milliez P, Girerd X, Plouin PF, et al. Evidence for an increased rate of cardiovascular events in patients with primary aldosteronism. J Am Coll Cardiol 2005;45:1243-8.

23. Stowasser $M$, Sharman $J$, Leano $R$, et al. Evidence for abnormal left ventricular structure and function in normotensive individuals with familial hyperaldosteronism type I. J Clin Endocrinol Metab 2005;90:5070-6.

24. Fassnacht M, Allolio B. Epidemiology of adrenocortical carcinoma. In: Hammer G, Else T, eds. Adrenocortical Carcinoma . 1st ed. New York: Springer; 2010:23-9.

25. Glomset $D$. The incidence of metastasis of malignant tumors to the adrenals. Am J Cancer 1938;32(1):57-61.

26. Abrams HL, Spiro R, Goldstein N. Metastases in carcinoma; Analysis of 1000 autopsied cases. Cancer 1950;3(1):74-85.

27. Lam KY, Lo CY. Metastatic tumours of the adrenal glands: A 30- year experience in a teaching hospital. Clin Endocrinol (Oxf) 2002; 56(1):95-101. 